Bader A. Alyoubi

University of Jeddah, Saudi Arabia

email: balyoubi@uj.edu.sa

Ibraheem M. Alharbi

University of Jeddah, Saudi Arabia

email:Imalharbi@uj.edu.sa

Adel A. Alyoubi

University of Jeddah, Saudi Arabia

email: balyoubi@uj.edu.sa

Alaa A. Qaffas

University of Jeddah, Saudi Arabia

email: aaqaffas@uj.edu.sa

Najah K. Almazmomi

University of Jeddah, Saudi Arabia

email: nkalmazmomi@uj.edu.sa

Correspondence author: balyoubi@uj.edu.sa

\title{
MANAGEMENT OF E-COMMERCE: IMPACT ON START-UP ECOSYSTEM
}

Abstract. The e-commerce sectoris one of the emerging and promising sectors. At the same time in the Kingdom of Saudi Arabia, as this sector is experiencing a significant growth spurt that makes it one of the sectors supporting the national economy by attracting more investments. In turn, it contributes to supporting GDP, as well as its role in creating more job opportunities for young people through expanding entrepreneurship and innovation. E-commerce contributes to creating new employment opportunities; Either by making it possible to establish small and medium-sized commercial projects for individuals and linking them to global markets at the lowest investment costs by creating a means of direct communication between the consumer and the product, or by providing them with job opportunities in many different fields related to ecommerce applications; Such as e-commerce website specialists, store workers, administrators, and technicians. Despite this, the success of the sector in fulfilling its targeted role according to the Kingdom's Vision 2030 remains subject to consumer awareness, their confidence in e-commerce, the logistics services and payments system. Besides, the communication infrastructure through the expansion of the number of POS devices at various payment outlets, they have indeed witnessed significant growth. It recorded nearly $62 \%$ during 2018 compared to the situation in 2017. However, the number of these devices is still needed to expand. The expanded role of this sector also requires taking into account work on organising many activities to educate citizens about the importance of this sector to the various global e-commerce sites and how to use them, taking into account the language so that there are no obstacles between the users of these sites. It should also work to consider the cost of shipping expenses so that everyone can spend their requirements through e-commerce sites. The Internet and the latest technological advancements resulted in the emergence of e-commerce. E-commerce is changing the business environment across the globe. However, the motivating factor for this research has been the lack of research linking the development of e-commerce and its impact on the start-up ecosystem that is specific to Saudi Arabia. There is a general agreement amongst the scholars and experts that start-up ecosystem plays a critical role in the country's economic system and e-commerce has become an integral part of that economic growth story of nations including Saudi Arabia. Therefore, the primary aim of this research was to examine the impact of e-commerce on start-up ecosystem in Saudi Arabia. The authors analysed the scientific journals and articles on the selected theme. The theoretical findings were put to the test using qualitative interviews that lasted between 30-45 minutes with eight highly skilled and experienced professionals in the field of ecommerce, start-up ecosystem, and management areas. Based on literature research and qualitative interviews, the key findings of this research are: (1) e-commerce and start-up ecosystem are amongst the key drivers of Saudi Arabia's economy, (2) e-commerce have a significant positive impact on start-up ecosystem of Saudi Arabia, and (3) e-commerce has facilitated the start-up ecosystem to become inclusive through the rise of women entrepreneurship in Saudi Arabia.

Keywords: e-commerce, start-up ecosystem, women entrepreneurship, internet technologies.

Cite as: Alyobi, B. A., Alharbi, I. M., Qaffas, A. A., \& Almazmomi, N. K. (2020). Management of E-Commerce: Impact on Start-Up Ecosystem. Marketing and Management of Innovations, 2, 247-255 http://doi.org/10.21272/mmi.2020.2-18 
B. A., Alyobi, I. M., Alharbi, A. A., Alyoubi, A. A., Qaffas, N. K., Almazmomi. Management of E-commerce: Impact on StartUp Ecosystem.

Introduction. As rightly suggested by Al-Shohaib, Al-Kandari, and Abdulrahim (2009), Internet technology has changed the dimension of doing business. E-commerce is proliferating due to its ability to eliminate intermediaries as companies can sell their products and services to consumers through the Internet, making it relatively easier (AIGhamdi, Drew and Alfarraj, 2011). E-commerce has emerged from being a technological issue to a business issue in the $21^{\text {st }}$ century.

Another such key driver of economic system is the "start-ups», and Alkhunaizan and Love (2013) suggested that a healthy start-up entrepreneurial environment spurs jobs creation, wealth creation, GDP growth, and improves the standard of living. Realising the potential of start-ups, big companies are outsourcing their tasks to start-ups, promoting innovation and healthy completion by helping the start-ups overcome cash flow problems (Almosa, 2011).

Although, e-commerce and start-ups are identified as key drivers of an economic system, very little research is available, linking both of them to understand the impact of e-commerce development on startup entrepreneurial environment. It is critical to understand this relationship given the huge investments being seen in e-commerce across the globe, including Saudi Arabia. This research primarily aims to contribute to this gap in knowledge by critically evaluating the e-commerce and start-up entrepreneurial environment in Saudi Arabia. E-commerce has made a big difference for women in Saudi Arabia who are pioneering the online fashion sector (Assaf, 2017). This situation, along with the median age of Saudi Arabia being just 30 years makes this research highly relevant and essential to gain insight into the effects of the development of e-commerce on start-up ecosystem in Saudi Arabia.

The research is carried out in four parts, which are discussed in the following paragraphs. The first part evaluates the "e-commerce business in Saudi Arabia». The second part examines the «start-up entrepreneurial environment in Saudi Arabia». The third part discusses the «impact of developing ecommerce on start-up entrepreneurial environment in Saudi Arabia». Furthermore, finally, "results and analysis of qualitative interviews» carried out with professionals and experts are presented that crossvalidates the findings of literature research.

The key findings of this research are:

(1) e-commerce and start-up ecosystem are amongst the key drivers of Saudi Arabia's economy;

(2) e-commerce has a significant positive impact on the start-up ecosystem of Saudi Arabia;

(3) e-commerce has facilitated the start-up ecosystem to become inclusive through the rise of women entrepreneurship in Saudi Arabia.

Literature Review. Ahmad and Agrawal (2012) explained that the Internet has evolved drastically since its inception and has survived even after the new network technology spawning from file sharing to remote log in and email to World Wide Web (WWW). This view was substantiated by Ries (2011), who stated that the Internet has transformed from the era of basic personal computers to communications in the portable form which includes laptops, smartphones, tablets, and others. As rightly explained by Barringer and Ireland (2019), the evolution of the Internet has always triggered the evolution of ecommerce that took off with the emergence of WWW and browsers in the 1990s. According to Barakat et al. (2018), the first stage of e-commerce started as merely selling goods online. In the second stage, it was realised that customers want a holistic experience like the facility to view invoices, order history, product recommendations, etc. and not just placing orders. As the Internet evolved, e-commerce evolved to its third stage by becoming customer-centric, and $72 \%$ of the businesses selling solely online (Gay, 2016). Assaf (2017) argued that as the Internet is still evolving, e-commerce is all set to cater to the future involving Artificial Intelligence, Virtual Reality and Internet of Things (IOT) and the future is looking bright for e-commerce which is predicted to facilitate $95 \%$ of purchases by 2040 .

Smith and Shao (2007) stressed on the importance of Internet security and its direct impact on ecommerce. They further explained that compromise on security could be fatal to e-commerce business as it can lead to a lack of trust amongst consumers, lousy company reputation, financial loss, etc. Figure 1 
B. A., Alyobi, I. M., Alharbi, A. A., Alyoubi, A. A., Qaffas, N. K., Almazmomi. Management of E-Commerce: Impact on StartUp Ecosystem.

shows that browsers are the second most exploited applications worldwide. Therefore, there is a constant need for research and development to overcome those security threats to make the e-commerce sector sustainable.

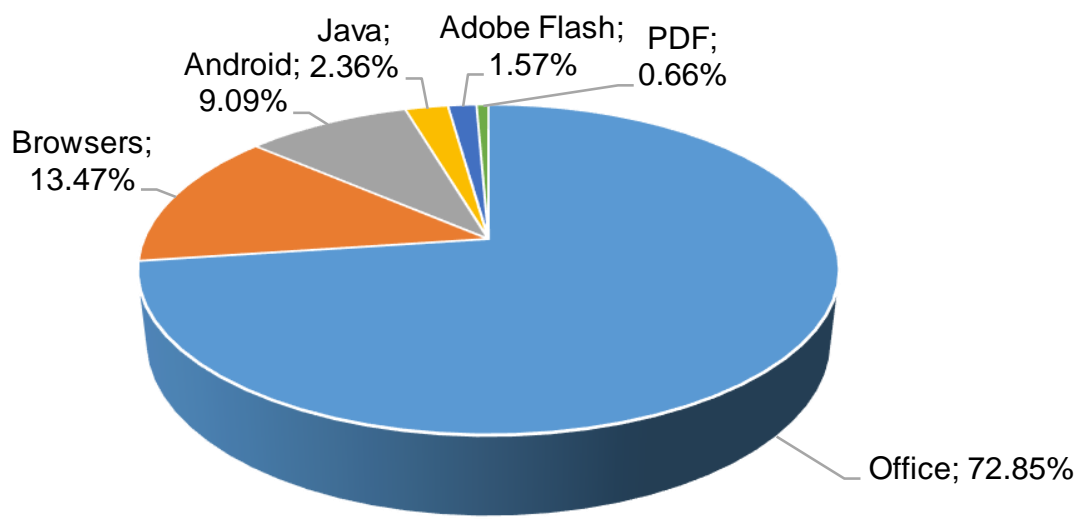

Source: Plecher (2019).

Figure 1. Commonly Exploited Applications Worldwide

Khan (2013) observed that for the e-commerce sector to flourish, four key factors are critical: (1) technological, (2) political, (3) social, and (4) economic. Technological factors refer to telecommunication infrastructure, access to the latest technological advancements, and cost-effective bandwidth availability. Political factors refer to government initiatives supporting the use and development of the latest technology, implementing reforms for growth and development of technology, and others. Social factors are related to the penetration rate of the Internet and the willingness of people to use technology. Economic factors refer to the average income of the people, cost of access to the latest technology, and economic growth of the country. When these factors are evaluated against the potential of Saudi Arabia, figure 2 indicates that Saudi Arabia is well placed to achieve more than 95\% Internet penetration rate by 2023 from the current impressive levels of around 88\% (Plecher, 2019). The government of Saudi Arabia is keen on the e-commerce sector, which is evident when they allocated more than $£ 600$ million for the implementation of the e-Government initiative in 2005. MAGNiTT (2019) reported that the government of Saudi Arabia had launched several initiatives for the achievement of Saudi Vision 2030. These initiatives are fostering entrepreneurship at a degree than ever before. The initiatives include venture investments for start-ups, mainly Saudi Arabia-based start-ups. It was a major initiative launched in 2018 to minimise the current funding gaps for start-ups. Lavelle et al. (2013) stated that the quality and quantity of deal flow of start-ups is increasing with the professional angel investors creating scalable start-ups.

A total of 30 institutions invested in Saudi-based start-ups in the first half of 2019 with local institutions, capital firms, and international investors. It is anticipated that through strategic initiatives on multiple verticals, Saudi Arabia has set its eye to become entrepreneurship hub of the region. Ries (2011) cited some examples to highlight the importance of start-ups for the nation's economy, like Infosys for India, brought a new wave of wealth creation amongst the middle-class working people. Similarly, Alibaba transformed the situation for Small and Medium Enterprises (SME) in China, and Google employees saw their net worth rise multifold. Impact of E-Commerce Sector Development on Start-Up Entrepreneurial 
B. A., Alyobi, I. M., Alharbi, A. A., Alyoubi, A. A., Qaffas, N. K., Almazmomi. Management of E-commerce: Impact on StartUp Ecosystem.

Environment in Saudi Arabia. Barringer and Ireland (2019) rightly argued that Saudi Arabia was late in realising the potential of e-commerce even though their readiness score was much higher than many other nations that have outperformed Saudi Arabia in terms of e-commerce. Figure 2 below shows the comparison of Saudi Arabia with other countries around the world. It can be noticed that Saudi Arabia had a higher readiness score (placed within red ellipse) than countries like China, India, Mexico, Indonesia, Argentina, and others (placed within green ellipse). However, Saudi Arabia did not capitalise on that as the countries mentioned above managed to achieve a higher growth rate in e-commerce while Saudi Arabia just saw the growth of slightly over $1 \%$ as of 2017 . However, Saudi Arabia has taken steps to make up for the failure to materialise its high readiness score into e-commerce growth by setting up an ambitious Saudi Vision 2030 with e-commerce playing a pivotal role in achieving that vision (Gay, 2017). Therefore, the development of e-commerce is vital for Saudi Arabia to ensure sustainable economic growth.

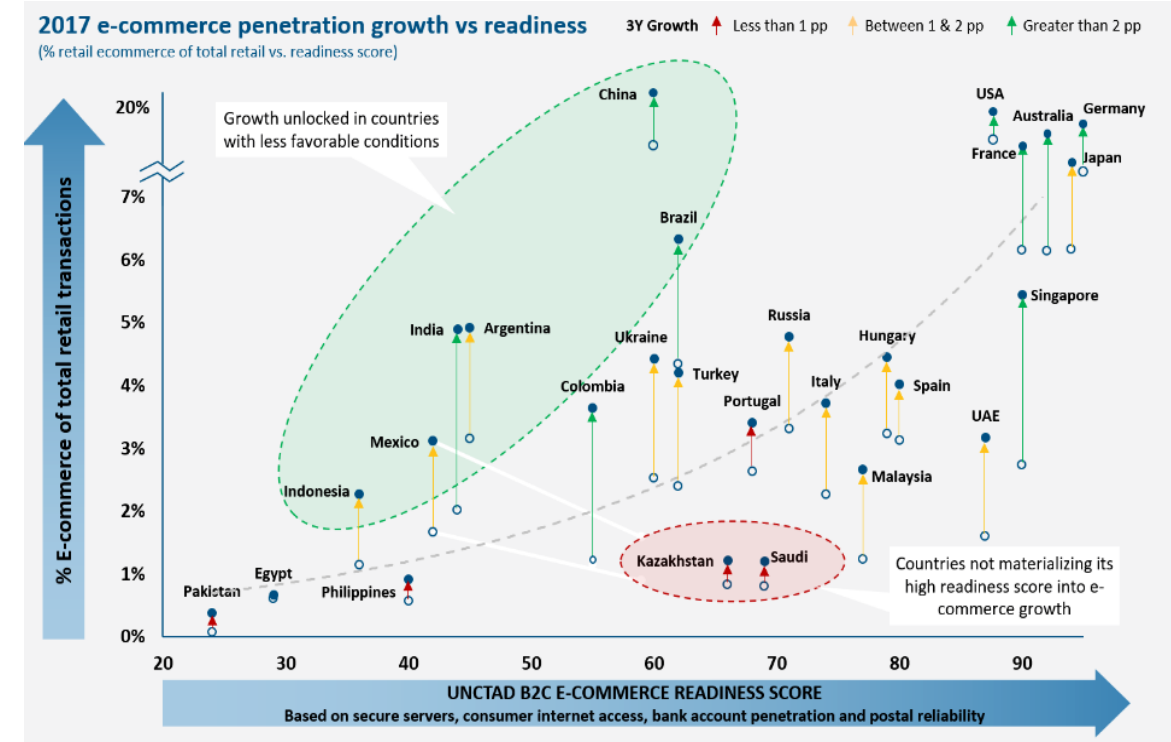

Figure 2. E-commerce Penetration Growth vs Readiness

Source: Barringer and Ireland (2019)

Even in terms of funding, $24 \%$ was grabbed by the e-commerce sector with an increase of $19 \%$ from the first half of 2018. It can be inferred from the above facts that e-commerce has a direct impact on startups to a significant extent. Barakat, Hill, and Akhrass (2018) conducted a detailed study on women entrepreneurship in Saudi Arabia and attributed the success of fashion e-commerce in Saudi Arabia to women entrepreneurs who benefited from the rise in e-commerce. The literature research has indicated that e-commerce and start-ups are critical drivers of growth for the country's economy. The literature research also confirmed that the development of the e-commerce sector is necessary, and it has a positive impact on the start-up entrepreneurial environment in Saudi Arabia. As suggested by Brinkmann \& Kvale (2015), validating theoretical findings adds credibility and quality to the research work. Using qualitative interviews, this research attempts to find answers to the research problem about what impact does the development of e-commerce have on start-up entrepreneurial environment in Saudi Arabia.

Methodology and research methods. Considering the complexity of the research topic and qualitative research approach offering the ability to unveil any hidden truths to the researcher, qualitative interviews were conducted to validate the theoretical findings explained in the earlier section. The interview 
B. A., Alyobi, I. M., Alharbi, A. A., Alyoubi, A. A., Qaffas, N. K., Almazmomi. Management of E-Commerce: Impact on StartUp Ecosystem.

participants were selected using the snowball and criterion sampling methods. The professionals and experts in the field of e-commerce, technology, and start-up businesses were selected for this research, making a combined experience of the participants exceeding 155 years. A total number of eight participants were selected that include experts from backgrounds that are relevant for this research, as shown in table 1. Ensuring all the relevant research ethics are strictly followed for this research, no sensitive information such as date of birth, address, and gender were collected as they are not necessary for this research topic and to maintain anonymity, but they were referred to as P1 through P8.

Table 1. Profile of Participants

\begin{tabular}{cccc}
\hline Participant & Designation & $\begin{array}{c}\text { Number of } \\
\text { Participants }\end{array}$ & $\begin{array}{c}\text { Experience in E-commerce, Start-ups, } \\
\text { Consumer Behaviour, and Marketing }\end{array}$ \\
P1 & Director of Finance & 1 & 22 years \\
P2 & Business Angel & 1 & 25 years \\
P3 & Senior Technology Consultant & 1 & 18 years \\
P4 & Business Angel & 1 & 20 years \\
P5 & Independent E-commerce Consultant & 1 & 17 years \\
P6 & Social Media Expert & 1 & 14 years \\
P7 & Independent Marketing and & 1 & 19 years \\
P8 & Consumer Behaviour Consultant & 1 & 22 years \\
\hline
\end{tabular}

Source: developed by the authors

Results. To help understand the findings, this section is divided into three parts similar to literature research section:

(1) e-commerce in Saudi Arabia;

(2) Start-up Entrepreneurial Environment in Saudi Arabia; Arabia.

(3) impact of e-commerce sector development on the start-up entrepreneurial environment in Saudi

The participants were asked the questions that fell into one of the above categories. The responses and analysis are explained in the following subsections.

1. E-commerce in Saudi Arabia. To gather information about the prevailing e-commerce situation in Saudi Arabia, the participants were asked to explain their views and opinions about the perception of ecommerce in Saudi Arabia. P4 explained that e-commerce has evolved in a big way, and Saudi Arabia is no different from any other country when it came to embracing e-commerce. P4, however, conceded that there was a bit of delay in fully accepting e-commerce in Saudi Arabia. P8 was of the view that Saudi Arabia is considered to be lagging in implementing latest technologies and the reason is primarily being lack of research that is specific to Saudi Arabia as it is culturally different from Western countries. P2 expressed that with the full backing of the government of Saudi Arabia, e-commerce has gained popularity immensely with more and more people liking the way of shopping e-commerce is offering. Similar views were shared by $\mathrm{P} 7$, who stated that people can now shop at their convenience online from anywhere using smartphones, laptops, desktop computers, and other gadgets. P8 explained that the critical feature of ecommerce is about establishing a direct connection between consumers and manufacturers eliminating the intermediaries resulting in lower prices for the products and services. P3 was of the view that the latest technological advancements, including the arrival of smartphones, have facilitated the businesses to reach out to people in remote areas and cater to their needs. P2 said that the spike in e-commerce investments is evident in the last few years as more and more e-commerce start-ups are garnering funds from various investors. The responses of the participants about the degree of conduciveness for e-commerce businesses are shown in figure 3 . 
B. A., Alyobi, I. M., Alharbi, A. A., Alyoubi, A. A., Qaffas, N. K., Almazmomi. Management of E-commerce: Impact on StartUp Ecosystem.

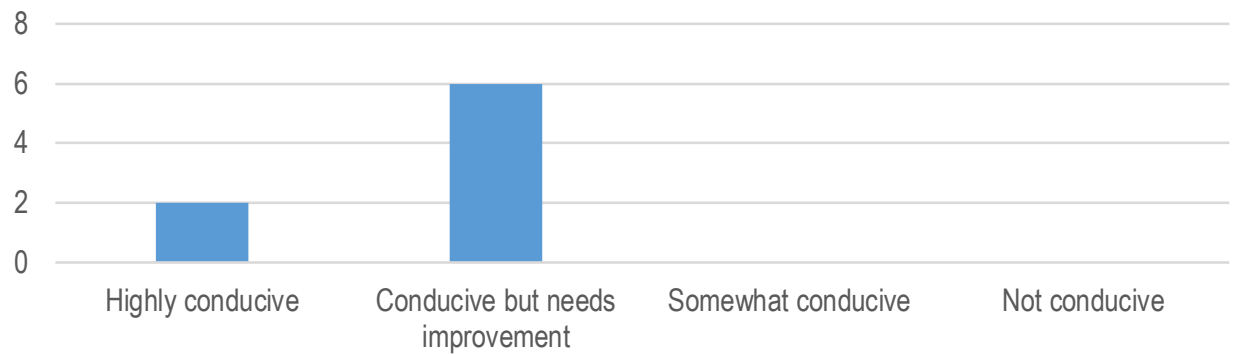

Figure 3. Degree of Conduciveness for E-commerce Business in Saudi Arabia, the number of participants

Source: developed by the authors.

2. Start-up Entrepreneurial Environment in Saudi Arabia. To understand the start-up ecosystem in Saudi Arabia, participants were asked several questions about challenges faced by aspiring entrepreneurs and existing conditions in Saudi Arabia. As mentioned earlier, the participants had immense knowledge and experience in start-up projects. P2 explained that with the Saudi Vision 2030, the government is encouraging start-ups in Saudi Arabia on a big scale. Their investment funding arm for start-ups as well as other local and international investors is the driving force behind the rapid growth of start-ups in Saudi Arabia. P7 shared similar views and added that this is the best phase for start-ups with plenty of opportunities, and e-commerce is one of the biggest favourites amongst the start-ups to attract huge investments. P5 expressed that historically, e-commerce is one of the highest funded sectors in MENA region and it is gaining further traction in the last few years, and with the growth percentage increasing year-on-year, it will not be surprising if it becomes the top-funded sector in Saudi Arabia. P1 suggested that government initiatives to fund the start-ups have been able to solve funding gaps for start-ups and have helped a lot in developing the start-up ecosystem in Saudi Arabia. P4 explained that the number of investors willing to fund start-ups had increased significantly, and the entry of both local and international investors has undoubtedly enhanced the quality of start-up ecosystem. P6 was of the view that the emergence of social media has helped start-ups achieve higher penetration rate in terms of marketing, expanding customer base, and reaching out to target audience in a cost-effective manner. Similar views were expressed by P8, who said that social media had facilitated the start-ups to keep their marketing strategies lean and focussed, resulting in value for their money spent on marketing and brand building. Therefore, some of the success factors behind healthy start-up ecosystem in Saudi Arabia are ecommerce, social media, and government initiatives. The responses from participants about the healthiness of start-up ecosystem in Saudi Arabia are shown in figure 4.

3. Impact of e-Commerce Sector Development on Start-up Entrepreneurial Environment in Saudi Arabia. The participants were asked to explain the impact of the development of e-commerce on start-up entrepreneurial environment in Saudi Arabia, which is the leading research topic.

P5 explained in greater detail that the significant impact of e-commerce start-up entrepreneurial environment in Saudi Arabia is that it brought in women entrepreneurs to the start-up ecosystem of Saudi Arabia. P7 also shared similar views and added that it is a well-known fact that women entrepreneurs add significant value to the ecosystem, and Saudi Arabia was behind other Western countries in this regard. E-commerce has offered a platform for women entrepreneurs, and now they are leading the fashion ecommerce in Saudi Arabia. 
B. A., Alyobi, I. M., Alharbi, A. A., Alyoubi, A. A., Qaffas, N. K., Almazmomi. Management of E-Commerce: Impact on StartUp Ecosystem.

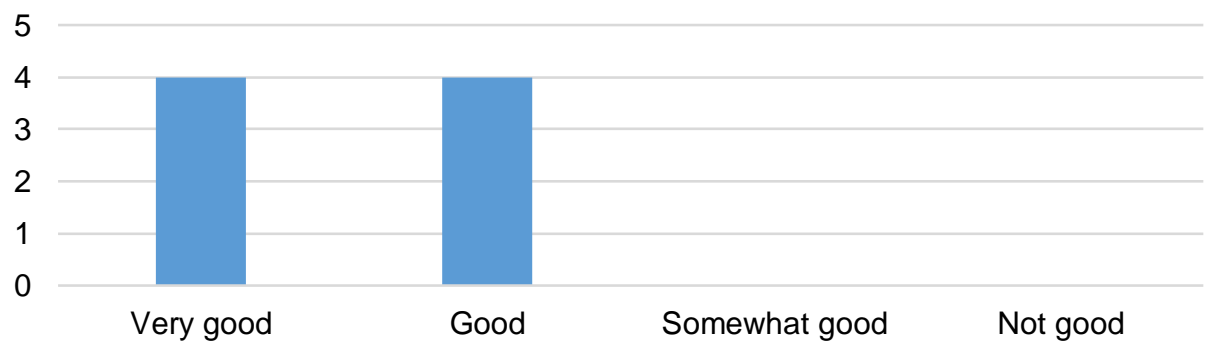

Figure 4. The healthiness of the Start-up Ecosystem in Saudi Arabia

Source: developed by the authors

P8 said that e-commerce has an enormous positive impact on multiple verticals of start-up ecosystem in Saudi Arabia. P8 elaborated and said that cost-effective marketing and facilitating the start-ups to sell directly to its consumers have made a big difference in margins and achieving breakeven point at a much faster pace. P2 said that earlier marketing used to take a big chunk of the budget, but with e-commerce in play, it has become much cheaper, resulting in reducing the business risk for start-ups. P6 also shared similar opinions that launching a start-up has become a lot cheaper due to reduced cost in marketing, distribution, and logistics. Manufacturers can directly sell their products and services without paying hefty fees to the middlemen. P3 said that it is a win-win situation for both buyers and sellers as buyers have the luxury of browsing and purchasing the products and services at their own time and from anywhere using the digital devices like smartphones, tablet, PC, laptop, and others. The start-up ecosystem has become more inclusive by offering opportunities to all sections of society. The responses of participants on the impact of e-commerce on start-up ecosystem are shown in figure 5. There was a general agreement amongst the participants that e-commerce has a high positive impact on start-up ecosystem.

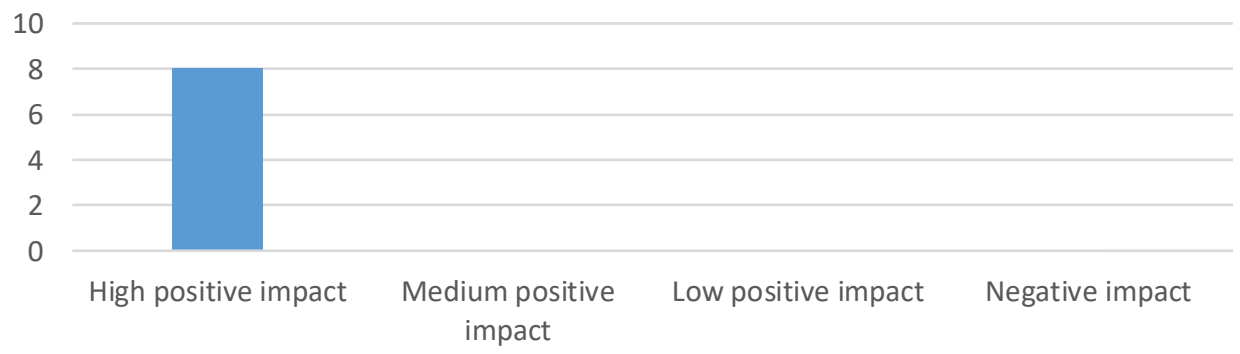

Figure 5. Impact of E-commerce on Start-up Ecosystem in Saudi Arabia

Source: developed by the authors

Conclusions. The primary aim of this research was to examine the impact of e-commerce on startup entrepreneurial environment in Saudi Arabia. To achieve that, a critical review of current e-commerce situation, prevailing start-up ecosystem in Saudi Arabia, and the importance of e-commerce and a healthy start-up ecosystem was carried out using extensive literature, journals, and articles from various experts and scholars. The literature research pointed out that the start-up ecosystem and e-commerce are amongst the key drivers of the nation's economic system. It has also been identified that e-commerce has a significant positive impact on start-up ecosystem. These findings were put to the test using qualitative 
B. A., Alyobi, I. M., Alharbi, A. A., Alyoubi, A. A., Qaffas, N. K., Almazmomi. Management of E-commerce: Impact on StartUp Ecosystem.

interviews with the highly skilled and experienced professional in the field of e-commerce, start-up, and management areas. The information gathered through these interviews validated the theoretical findings. This research recommends the nurturing of start-up ecosystem in Saudi Arabia by using e-commerce as a catalyst in building a healthy start-up ecosystem. This research concludes by strongly stressing on the crucial role start-up ecosystem has to play in achieving the Saudi Vision 2030.

This research specifically focused on Saudi Arabia, and it has been the limitation of this research. However, the findings and theoretical underpinnings can be used by researchers, academicians, and management people working across the world.

This research serves as a pointer for fellow researchers to take further research work related to Big Data, Cloud Computing, and their relationship with e-commerce sector and start-up ecosystem in Saudi Arabia and other parts of the world. E-commerce has the potential to contribute to the economy in a big way, and therefore, research about e-commerce and new technologies must be an ongoing process.

Author Contributions: conceptualisation, B.A., I. A., N.A; methodology, B.A., A. A., N. A.; validation, B. A. A. A., A. Q., N. A.; resources, B. A., A. A., N. A.; data curation, B. A., A. Q., I. A., N. A.; writing-original draft preparation B. A, A. A., N. A.; writing review and editing I. A., A. Q., N. A.; visualisation B. A., N. A.; supervision, B. A., A. A., N. A.; project administration, B. A., A. Q.

\section{References}

Ahmad, I. \& Agrawal, A. M. (2012). An Empirical Study of Problems in Implementation of Electronic Commerce in Kingdom of Saudi Arabia. International Journal of Business and Management, 7(15), 70-80. [Google Scholar] [CrossRef]

AlGhamdi, R., Drew, S., \& Alfarraj, O. (2011). Issues Influencing Saudi Customers' Decisions to Purchase from Online Retailers in the KSA: A Qualitative Analysis. European Journal of Scientific Research, 4, 580-593. [Google Scholar]

Alkhunaizan, A. \& Love, S. (2013). Effect of demography on mobile commerce frequency of actual use in Saudi Arabia. Advances in information systems and technologies, 206, 125-131. [Google Scholar] [CrossRef]

Almosa, M. (2011). Profiling E-buyers in Saudi Arabia: Saudi Arabia as A Promising Developing Country. Cross-cultural Communication, 7(2), 92-100. [CrossRef]

Al-Shohaib, K., Al-Kandari, A. A., \& Abdulrahim, M. A. (2009). Internet Adoption by Saudi Public Relations Professionals. Journal of Communication Management, 13(1), 21-36. [Google Scholar] [CrossRef]

Assaf, T. (2017). The Kingdom of Saudi Arabia: Status of the entrepreneurship ecosystem. WAMDA: Amman, Jordan,55. Retrieved from https://backend.wamda.com/api/v1/downloads/publications/kingdom-saudi-arabia-status-entrepreneurshipecosystem

Barakat, H., Hill, S. \& Akhrass, E. (2018). Women and Entrepreneurship in the Contemporary Middle East. KnE Social Sciences, 3(10), 20. [Google Scholar]

Barringer, B. R. \& Ireland, R. D. (2019). Entrepreneurship: successfully launching new ventures (6 $6^{\text {th }}$ Edition). New York, NY: Pearson. Retrieved from https://www.pearsonhighered.com/assets/preface/0/1/3/4/013489149X.pdf

Brinkmann, S., \& Kvale, S. (2015). Interviews: Learning the craft of qualitative research interviewing (Vol. 3). Thousand Oaks CA: Sage. [Google Scholar]

Gay, K. (2016). Women entrepreneurs. New York, NY: Enslow Publishing. [Google Scholar]

Khan, M. R. (2013). Mapping entrepreneurship ecosystem of Saudi Arabia. World Journal of Entrepreneurship, Management and Sustainable Development, 9(1), 28-54. [Google Scholar] [CrossRef]

Lavelle, K., \& Al Sheikh, H. (2013). Giving voice to women entrepreneurs. Women's Entrepreneurship Initiative in collaboration with Ashridge Business School in Saudi Arabia. Retrieved from https://www.ellesolaire.org/wp-content/uploads/2017/04/Final-Execsummary-women-entrepreneurs-in-Saudi-Arabia-Report-Executive-Summary.pdf

MAGNiTT (2019). H1 2019 Saudi Arabia Ventura Capital Snapshot. Riyadh: MAGNiTT. Retrieved from https://investsaudi.sa/media/1749/magnitt_svc h1_2019 en.pdf

Plecher. H. (2019). Saudi Arabia-Statistics and Facts. Retrieved from https://www.statista.com/topics/1630/saudi-arabia/

Ries, E. (2011). The lean start-up: How today's entrepreneurs use continuous innovation to create radically successful business. New York: Crown Business. [Google Scholar] [CrossRef]

Smith, R. \& Shao, J. (2007). Privacy and e-commerce: a consumer-centric perspective. Electronic Commerce Research, 7(2), 89-116. [Google Scholar] [CrossRef] 
B. A., Alyobi, I. M., Alharbi, A. A., Alyoubi, A. A., Qaffas, N. K., Almazmomi. Management of E-Commerce: Impact on StartUp Ecosystem.

Бадер А. Альоубі,

Університет імені короля Абдель Азіза, Саудівська Аравія

Ібрагім М. Аль-Харбі,

Університет імені короля Абдель Азіза, Саудівська Аравія

Адель А. Альоубі,

Університет імені короля Абдель Азіза, Саудівська Аравія

Алаа А. Кафффас

Університет імені короля Абдель Азіза, Саудівська Аравія

Наджах К. Аль-Мазумі,

Університет імені короля Абдель Азіза, Саудівська Аравія

Управління електронною комерцією: вплив на екосистему стартапів

Стрімкий розвиток інтернету та новітніх технологій обумовили розвиток електронної торгівлі. Результати систематизації літературних джерел свідчать про обмеженість існуючих наукових напрацювань щодо розвитку електронної комерції та ії впливу на екосистему сатрапів у Саудівській Аравії. Головною метою статтіє аналіз впливу електронної торгівлі на розвиток стартапів у Саудівській Аравії. Вибірку даних сформовано на основі результатів опитування восьми висококваліфікованих та досвідчених фрахівиів у сфрері електронної комериії, розвитку стартапів та менеджменту. Методологію дослідження засновано на глибинному інтерв'ю тривалістю від 30 до 45 хвилин. Для досягнення поставленої мети авторами критично оцінено низку літературних джерел з досліджуваної тематики. У статі встановлено, що електронна торгівля сприяє розвитку національної економіки шляхом залучення додаткових інвестицій. При цьому розвиток підприємниитва та інноваційності електронної торгівлі сприяє зростанню можливостей працевлаштування молоді у різних сферах діяльності, які мають відношення до електронної комерції, серед яких: фрахівці вебсайтів електронної торгівлі, працівники онлайн-магазинів, технічні спеціалісти. У статті зазначено, що сектор електронної комерції сприяє створенню малих та середніх комерційних проектів фозичними особами, виводячи їх на глобальний ринок при низькому рівні інвестиційних витрат. Авторами доведено, що еффективність функиіонування сектору електронної торгівлі та виконання ним цільових таргетів «Стратегічних цілей 2030 Королівства» залежить від рівня обізнаності споживачів, довіри до електронної торгівлі, якості логістичних послуг, системи платежів та комунікаційної інфраструктури, яка забезпечується через розширення системи POS-терміналів у різних торгових точках. Згідно зі статистичними даними, кількість POS-терміналів у 2018 році зросла майже на $62 \%$ у порівнянні з 2017 роком. Зростання ролі сектору електронної торгівлі передбачає організацію низки заходів для підвищення рівня обізнаності споживачів про ффункиіонування сектору електронної тореівлі шляхом промоції світових веб-сайтів електронної комерції. Споживачі повинні знати принципи ффункціонування офріційного веб-сайту, мову інтерфеейсу та умови доставки для безперебійної взаємодії із відповідним веб-сайтом. За отриманими теоретичними та практичними результатами дослідження, авторами визначено, що: електронна комерція як стартап $є$ одними із ключових рушійних сил економічного розвитку Саудівської Аравії; електронна комерція має статистично значущий позитивний вплив на удосконалення екосистеми стартапів Саудівської Аравії; електронна комерція сприяє досягненню інклюзивності стартапів у Саудівській Аравії через зростання питомої ваги жіночого підприємництва.

Ключові слова: електронна комерція, стартап екосистеми, жіноче підприємництво, інтернет технології.

Manuscript received: 19.12.2019

(C) The author(s) 2020. This article is published with open access at Sumy State University. 